Folia Historica Cracoviensia, 22: 2016, s. 649-656

DOI: http://dx.doi.org/10.15633/fhc.2101

ks. Bogdan Stanaszek

Uniwersytet Papieski Jana PawŁa iI w Krakowie

\title{
Dominika Kuśnierz-Krupa, Fundacje miejskie benedyktynów tynieckich w Małopolsce potudniowej w okresie Średniowiecza, Politechnika Krakowska, Kraków 2014, ss. 217
}

Książka Dominiki Kuśnierz-Krupy nosi tytuł, który sugeruje, że Autorka zajmuje się tematem typowym dla mediewistów. Tymczasem praca w istocie poświęcona jest kwestiom związanym ze średniowieczną urbanistyką i architekturą trzech miast należących do opactwa benedyktynów w Tyńcu (Brzostek, Kołaczyce i Tuchów) ${ }^{1}$. Należałoby więc wprowadzić podtytuł, który precyzowałby zakres podjętych badań (np. Studium z zakresu urbanistyki i architektury). Autorka zdaje się jednak nie zauważać problemu, gdyż na s. 11 pisze: „Niniejsza monografia ma na celu przedstawienie średniowiecznej historii miast należących do włości klasztoru Benedyktynów w Tyńcu”. Jeśli praca miałaby wnosić coś do badań w tym zakresie, należałoby postulować przeprowadzenie szeroko zakrojonych poszukiwań archiwalnych, tymczasem Autorka ogranicza się do wykorzystania publikowanych źródeł i niektórych opracowań. Tym samym nie poszerza naszej wiedzy na temat „średniowiecznej historii miast”. Nie w tym jednak tkwi największy problem. Po przejrzeniu bibliografii i przypisów okazuje się, że Autorka nie wykorzystała ważnych publikacji dotyczących podjętego tematu. Widać to dobitnie w przypadku Brzostku. Dominika Kuśnierz-Krupa zauważyła trzy opracowania, jak pisze, „o charakterze monograficznym”: Brzostek. 640-lecie lokacji miasta (1367-2007). Tradycje - perspektywy rozwoju pod redakcją Bogdana Stanaszka; tegoż autora Brzostek i okolice oraz Dzieje miasta Brzostku Mariana Nałęcz-Mysłowskiego. Właściwie żadna z tych pozycji nie rości sobie pretensji do miana monografii - co zresztą Autorka w kolejnym zdaniu zauważa. Pierwsza jest publikacją popularnonaukową, podobnie druga, stanowiąca rodzaj przewod-

\footnotetext{
Nie są to bynajmniej wszystkie ośrodki miejskie należące do wspomnianego opactwa, lepiej więc byłoby wymienić nazwy tych miast w tytule książki.
} 
nika turystycznego. Ostatnia z wymienionych to zaledwie broszura wydana w 1871 roku. Trudno dociec, dlaczego Autorka nie wpisała hasła „Brzostek” w internetowym katalogu Biblioteki Narodowej i Biblioteki Jagiellońskiej lub czemu nie skorzystała z zasobów Biblioteki Gminnej w Brzostku (deklarowała prowadzenie badań w terenie). Znalazłaby tam bez trudu podstawowe publikacje, bez których podjęcie badań nad przeszłością Brzostku wydaje się co najmniej wątpliwe. Są to zarówno opracowania ${ }^{2}$, jak i publikacje źródeł (zawarte głównie w „Roczniku Brzosteckim” oraz w ramach serii: $Z$ dziejów Brzostku. Studia i materiały $\left.{ }^{3}\right)$. Wystarczy wspomnieć, że wydano drukiem prawie wszystkie protokoły wizytacji parafii Brzostek z przełomu XVI i XVII wieku ${ }^{4}$, inwentarze klucza brzosteckiego Z 1691 i 1720 roku $^{5}$ oraz metryki: józefińską i franciszkańską ${ }^{6}$. Źródła te mają wręcz kapitalne znaczenie dla badań nad przestrzenią miast. W tym wypadku nie

2 Zob. P. Sczaniecki, Miejska lokacja Brzostku, „Rocznik Brzostecki” 2 (1994), s. 7-11; P. Sczaniecki, Między Brzostkiem a Kleciami (wiadomości o życiu religijnym na schyłku średniowiecza), „Rocznik Brzostecki” 3 (1997), s. 7-11; B. Stanaszek, Z dziejów Brzostku, Wydarzenia i ludzie, Brzostek 2007 (m.in. publikowane i przetłumaczone przez Krzysztofa Tyburowskiego dokumenty lokacyjne miasta z 1367 i 1394 roku); B. Stanaszek, Ludność i zabudowa Brzostku w świetle inwentarzy z przełomu XVII i XVIII w., [w:] Z dziejów Brzostku. Studia i materiaty, t. 2, red. B. Stanaszek, Brzostek 2009, s. 59-112; B. Stanaszek, Terytorium, zabudowa i ludność Brzostku w pierwszym półwieczu rządów austriackich w Galicji, [w:] Z dziejów Brzostku. Studia..., t. 2, dz. cyt., s. 133-167; B. Stanaszek, Stary cmentarz w Brzostku, Brzostek 2013; B. Stanaszek, Jan z Kijan, Januarius Sovizralius, Jan Dzwonowski - dwa pseudonimy, jedno nazwisko? Rzecz o tożsamości plebejskiego poety, „Pamiętnik Literacki” (2013) nr 3, s. 207-216; B. Stanaszek, Brzostek - tradycje historyczne, Brzostek 2014 (praca ta ukazała się w tym samym roku, co recenzowane opracowanie, można więc przyjąć, że skorzystanie z niej było niemożliwe).

3 Zob. A. Bejska, Wspomnienia o dawnym Brzostku, „Rocznik Brzostecki” 1 (1993), s. 78-99 (opisana topografia miasteczka z okresu międzywojennego); M. Wojnarowska, K. Tyburowski, Parafia Brzostek i Przeczyca w „Liber beneficiorum” Jana Długosza, „Rocznik Brzostecki” 5 (19992001), s. 41-67; Źródła, [w:] Z dziejów Brzostku. Studia..., t. 2, dz. cyt., s. 185-306 (20 dokumentów dotyczących różnych aspektów funkcjonowania miasta z okresu staropolskiego); Źródła, [w:] $Z$ dziejów Brzostku. Studia i materiały, t. 3, red. B. Stanaszek, Brzostek 2012, s. 54-161 (16 dokumentów z okresu staropolskiego, w tym niezmiernie cenny dla opisywanego tematu: Brzostek, 2 września 1546 r., Jordan Spytek Wawrzyniec z Zakliczyna i Melsztyna oraz Jan Trzecieski z Ratoszyna i Dębicy poświadczaja, przedłożony przez opata tynieckiego, przywilej uposażenia wójtostwa w Brzostku, ed. P. Stanko, tłum. M. Kozera, s. 54-76).

${ }^{4}$ Zob. Parafia Brzostek $w$ świetle wizytacji Radziwiłłowskiej, ed. i tłum. M. Kozera, [w:] Z dziejów Brzostku. Studia..., t. 2, dz. cyt., s. 211-228; Wizytacja kościołów w Brzostku i Kleciach $z 1610$ roku, red. i tłum. M. Kozera, [w:] Z dziejów Brzostku. Studia..., t. 2, s. 229-244; M. Kozera, Stan kościoła w mieście Brzostku i Kleciach w świetle wizytacji z 1618 r., „Studia Sandomierskie” 17 (2010) $\mathrm{nr}$ 4, s. 109-120.

5 Zob. B. Stanaszek, Ludność i zabudowa..., dz. cyt., s. 75-112.

6 Zob. B. Stanaszek, Terytorium, zabudowa i ludność..., dz. cyt., s. 146-167. 
było nawet potrzeby korzystania z zasobu Centralnego Archiwum Historycznego we Lwowie, Archiwum Głównego Akt Dawnych w Warszawie, zbioru rękopisów Zakładu Narodowego im. Ossolińskich we Lwowie i Biblioteki Jagiellońskiej w Krakowie. Wystarczyło sięgnąć do wydanych drukiem książek! Analogiczne źródła dotyczące Kołaczyc i Tuchowa dostępne są w formie rękopisów.

Tak więc już na wstępie zauważamy bardzo poważne braki dotyczące bibliografii, choć z drugiej strony Autorka wykorzystała dużą grupę opracowań, w tym trudno dostępnych (np. praca Adolfa Hirschberga'). Ciężko się zorientować, jakie archiwa zostały przebadane w poszukiwaniu źródeł kartograficznych, gdyż bibliografia nie zawiera takiego zestawienia. Czytelnik musi więc śledzić kolejne przypisy i podpisy pod ilustracjami. Możemy zauważyć wykorzystanie tzw. mapy Miega przechowywanej w Kriegsarchiv w Wiedniu ${ }^{8}$ (odnotujmy, że rysunek rynku brzosteckiego jest schematyczny i nie oddaje dokładnie przebiegu sieci drożnej; nie zaznaczono nawet ratusza, który z pewnością stał na środku rynku $)^{9}$. Na potrzeby książki wykorzystano też mapy katastralne przechowywane w Archiwum Państwowym w Rzeszowie. Szkoda, że autorka nie sięgnęła do zespołów: Archiwum Geodezyjne Brzostek i Kołaczyce, przechowywanych w Archiwum Państwowym w Przemyślu. Tamtejsze materiały pozwalają na ustalenie dokładnej lokalizacji domów (numery w spisie odpowiadają umieszczonym na mapie). Można też poznać nazwiska właścicieli, co $\mathrm{z}$ kolei pozwala na zestawienie tych danych z metrykami kościelnymi. Chociaż są to informacje z połowy XIX wieku, konfrontując je ze starszymi inwentarzami, możemy śledzić zmiany zachodzące w miejskiej zabudowie, jak również poznać profesje mieszkańców.

Na pochwałę zasługuje wykorzystanie w książce wyników najnowszych badań archeologicznych oraz zdjęć lotniczych, których analiza jest bardzo cenna dla uchwycenia lokalnej topografii.

Niestety wskazane braki w zakresie bibliograficznym odcisnęły piętno na treści analiz przeprowadzonych w recenzowanej książce. Nie znając źródeł i opracowań, Autorka nie była w stanie prawidłowo identyfikować poszczególnych obiektów.

7 Zob. A. Hirschberg, Stosunki osadnicze w dobrach klasztoru tynieckiego w początkach jego istnienia, Lwów 1925.

8 Karty dotyczące Brzostku i Kołaczyc mają odpowiednio sygn. BIXa39o, col. XI, section o75; BIXa39o, col. XI, section 076. Zostały opublikowane w: B. Stanaszek, Z dziejów Brzostku. Wydarzenia..., dz. cyt., s. 42-45. O brzosteckim ratuszu patrz: tamże, s. 31-36.

$9 \quad$ O schematycznym układzie tego fragmentu mapy świadczą opisy zawarte w metryce józefińskiej. Centralne Archiwum Historyczne we Lwowie, fond 19, opis 2, sprawa 318, k. 61-62; B. Stanaszek, Terytorium, zabudowa i ludność..., dz. cyt., s. 146nn. Na mapie nie zaznaczono m.in. dróg wychodzących w stronę dworu w Nawisu i w kierunku młyna „pod miastem”. 
Wyliczmy ważniejsze uchybienia dotyczące Brzostku. Przykładowo w podrozdziale o szkole (s. 124-125) można było bardziej precyzyjnie wskazać miejsce, gdzie stała ona pod koniec XVI wieku (informacje na ten temat podają wizytacje biskupie). W analizach wypadało uwzględnić, oprócz świątyń i kaplic, również budynki kościelne (plebania, folwark, wikarówka, domy służby), gdyż odgrywały one ważną rolę w życiu średniowiecznego miasteczka. Niestety w książce brak informacji na ten temat ${ }^{10}$. W przypadku podrozdziału poświęconego karczmom (s. 137nn) autorka nie odczytała właściwie oznaczeń na mapie katastralnej (ryc. 114) i pominęła kilka obiektów pełniących funkcje zajazdów. Inną sprawą jest, czy stan $\mathrm{z}$ połowy XIX wieku można $\mathrm{w}$ tym przypadku odnosić do okresu średniowiecza. Wydaje się to mocno wątpliwie, gdyż prawie cała zabudowa miasta uległa zniszczeniu w czasie najazdu wojsk węgierskich Jerzego II Rakoczego w 1657 roku. Stopniowa odbudowa z pewnością zatarła przynajmniej część dawnego układu przestrzennego. Wypada podkreślić, że spisy mieszkańców sprzed tej katastrofy (1657) i po niej (1691), wskazują na dramatyczny spadek zaludnienia i odpływ ludności. Pojawiały się natomiast nowe rodziny, które budując domy, nie kierowały się sentymentami (jak chęć przywrócenia poprzedniego stanu), a nawet mogły nie wiedzieć, gdzie dawniej stały domy zajezdne. Wznoszono budowle na działkach, które otrzymywano od zarządcy brzosteckiego dworu ${ }^{11}$. Znacznie bardziej stabilnymi obiektami były młyny i kuźnie (o tych ostatnich autorka nie pisze w ogóle), gdyż ich urządzenie wymagało większych nakładów inwestycyjnych. Tak wiec wskazanie miejsc, gdzie stały niegdyś dwa brzosteckie młyny, dla osoby znającej topografię miasteczka, nie sprawia żadnych kłopotów. Jeden, określony w inwentarzu z 1722 roku jako położony „pode dworem” (inne źródła precyzują - naprzeciw plebanii), widoczny jest na mapie Miega. Drugi, „pod miastem”, można odszukać na mapie katastralnej z połowy xıx wieku. Funkcjonował do czasów II wojny światowej, dziś w sąsiedztwie znajduje się mostek na potoku Słony w ciągu ul. Królowej Jadwigi. Bez ryzyka większego

10 Zob. B. Stanaszek, Jan z Kijan..., dz. cyt., s. 213. Znajdujemy tam opis położenia budynków plebańskich i domu rektora szkoły. Na s. 124 Autorka przekręciła nazwisko brzosteckiego proboszcza Jana Żardeckiego (w książce czytamy: Jan Zawadzki).

${ }^{11}$ Np. karczma zlokalizowana w sąsiedztwie kościoła brzosteckiego, o której Autorka pisze, została zbudowana na polecenie opata tynieckiego Stanisława Bartoszewskiego w 1750 roku na gruncie zabranym rodzinie Tułeckich. Nie ma przesłanek, by twierdzić, że wspomniani mieszczanie wcześniej posiadali dom zajezdny. Zob. [Brzostek, 1758], Zeznanie mieszczan brzosteckich $w$ sprawie krzywd uczynionych przez opata tynieckiego Stanistawa Bartoszewskiego, adresowane do prymasa Polski Adama Ignacego Komorowskiego, ed. B. Stanaszek, [w:] Z dziejów Brzostku. Studia..., t. 2, dz. cyt., s. 275-276. 
błędu można przyjąć, że lokalizacje te nie uległy zmianie od czasów średniowiecza. Autorka prawidłowo wskazała pierwszy z tych obiektów (s. 150). Natomiast drugi, zaznaczony przez nią ma mapie Miega, to młyn w Woli Brzosteckiej, który funkcjonował już przed połową XVI wieku. W 1545 roku napadł nań wójt brzostecki Adam Białowodzki i przepędził tamtejszego młynarza. Dało to początek długim sporom $\mathrm{z}$ właścicielem drugiej części wójtostwa brzostekicgo i wójtostwa w Woli - Janem Uchaczem, i z jego następcą Piotrem Jarzyną ${ }^{12}$.

Również analiza sieci drożnej i linii „obwodu obronnego” (ryc. 50) budzi zastrzeżenia. Autorka prawidłowo wskazała dawny przebieg traktu węgierskiego w kierunku Pilzna i Jasła (s. 54). Jednak droga, którą określa mianem prowadzącej do Frysztaka (dziś ul. Mysłowskiego w kierunku Nawsia Brzosteckiego), miała charakter lokalny - wiodła do dworu wójtowskiego na Przedmieściu. Nie mógł nią przebiegać większy ruch, gdyż teren dworski był ogrodzony. Możemy się domyślać, że chłopi i mieszczanie korzystali z innej drogi biegnącej po lewej stronie potoku Słony od „Nawsieński karczmy” „popod samą plebanię” (1788 r.) ${ }^{13}$. Niewykluczone, że w średniowieczu połączenie to miało ponadlokalne znaczenie. Droga biegła dalej na Wolę Brzostecką i przez Kamienicę Górną (obok tzw. Zamkowej Góry) w stronę Chełmu (w Xvi wieku znane miejsce odpustowe). Jednak nie była to właściwa droga do Frysztaka. Ta wiodła $\mathrm{z}$ brzosteckiego rynku obok kościoła farnego (trakt węgierski), a następnie skręcała na południowy-wschód w kierunku Opacionki i Gogołowa (dzisiejsza ul. Słoneczna) ${ }^{14}$.

Zauważamy też błędy w wytyczeniu linii, którą mogły zajmować domniemane umocnienia miejskie - zapewne drewniana palisada (mapa na s. 95). Co prawda autorka dobrze skorygowała jej przebieg od strony północno-zachodniej za tzw. „starą Kasą” (błędnie wykreślono ją w publikacji Jana Malczewskiego) ${ }^{15}$, jednak nieprawidłowo wyznaczyła linię od strony zachodniej. Na jej mapie biegnie u podnóża skarpy brzosteckiej, wzdłuż ulicy podwalnej (dziś: 20 Czerwca). Należało wyrysować ją nie u podnóża, ale na kulminacji skarpy (co stwierdza sama Autorka - s. 93), bo tylko wówczas mogła być wykorzystana do obrony. Podobny błąd można zauważyć na wspomnianej mapie od strony północno-wschodniej - gdzie linia biegnie również podwalem (za dzisiejszym Urzędem Gminy i ul. Królowej Jadwigi). Pewno Autorka nie zauważyła tych szczegółów

12 Zob. B. Stanaszek, Z dziejów Brzostku. Wydarzenia..., dz. cyt., s. 24-30.

13 Zob. CAHL, fond 19, opis 2, sprawa 318, k. 61.

${ }_{14}$ O drodze prowadzącej w Xvi wieku z Brzostku do Frysztaka piszą: S. Cynarski, T. Sławski, Pisarze sowizdrzalscy z Podgórza, „Pamiętnik Literacki” 55 (1964) z. 1-2, s. 444.

15 Zob. J. Malczewski, Miasta między Wisłoka a Sanem do początków XVI w. Powstanie - zagospodarowanie - układy przestrzenne, Rzeszów 2006, s. 472. 
w czasie krótkiej wizji lokalnej, ale można było to skorygować na podstawie analizy mapy wysokościowej. Poziomice wyznaczające przebieg wzniesienia nie kłamią. Spoglądając na mapę, możemy również domyślać się dodatkowej furty w obwodzie obronnym przy uliczce prowadzącej do młyna („pod miastem”), ale to musi pozostać w sferze spekulacji.

Zastrzeżenia budzi też przedstawiona w książce analiza historii miast (s. 45-50). W przypadku Brzostku Dominika Kuśnierz-Krupa prawidłowo rozróżniła lokację Brzostku opackiego (1367 r.) i bliźniaczego Małego Brzostku, miasta fundowanego przez króla Władysława Jagiełłę w 1394 roku (tym samym poprawiła błąd Mieczysława Książka ${ }^{16}$ ). Nie uwzględniła jednak najnowszych ustaleń wskazujących, że zasadźca Małego Brzostku Stanisław z Sąspolina to Stanisław z Sąspowa, wioski położonej w starostwie ojcowskim. Jego potomkowie w XV wieku weszli w posiadanie wójtostwa w Brzostku opackim. Jeden z potomków Stanisława Mikołaj Sąspowski, zaczął używać nazwiska Białowodzki. Analizując dokumenty źródłowe, można się było pokusić o próbę wskazania lokalizacji dworów wójtowskich $^{17}$ (Autorka wykorzystała do tego jedynie źródła kartograficzne z wieków XVIII-XIX, które nie w pełni oddają stan z okresu średniowiecza).

Powyższe uwagi pokazują, że przeprowadzenie analiz topograficznych i próba odtworzenia układu przestrzennego średniowiecznego miasta jest zadaniem trudnym. Wymaga dogłębnych badań nad materiałami archiwalnymi, prowadzenia uważnych studiów w terenie. Materiały kartograficzne i fotograficzne powinny być konfrontowane $\mathrm{z}$ inwentarzami i metrykami kościelnymi. To zadanie niezmiernie ciekawe, ale też ryzykowne. Próba szybkiego wyciągania wniosków z pominięciem ważnych materiałów archiwalnych i publikacji nie może przynieść dobrego efektu. Praca Dominiki Kuśnierz-Krupy może być zaliczana do pionierskich, choć wcześniej podejmowano już analogiczne analizy w odniesieniu do przynajmniej niektórych ze wspomnianych miast (Książek ${ }^{18}$, Malczewski). Czy jest jednak próbą udaną? Wobec wyliczonych braków trudno precyzować twierdzącą odpowiedź. Autorka powinna gruntownie przemyśleć stosowaną przez siebie metodologię, tym bardziej że zamierza przygotować kolejne publikacje dotyczące rozwoju przestrzennego miast (Wstęp, s. 7).

${ }^{16}$ Zob. M. Książek, Układy urbanistyczne niektórych zabytkowych miasteczek $w$ województwie rzeszowskim, „Materiały Muzeum Budownictwa Ludowego w Sanoku” (1973) nr 17-18, s. 12.

17 Por. B. Stanaszek, Stary cmentarz..., dz. cyt., s. 17-25.

18 M. Książek, Układy urbanistyczne..., dz. cyt., s. 7-27. 


\section{Bibliografia}

\section{Źródła archiwalne}

Centralne Archiwum Historyczne we Lwowie, fond 19, opis 2, sprawa 318.

Kriegsarchiv w Wiedniu, sygn. BIXa390, col. XI, section 075, BIXa390, col. XI, section o76.

\section{Źródła drukowane}

Bejska A., Wspomnienia o dawnym Brzostku, „Rocznik Brzostecki” 1 (1993), s. 78-99. [Brzostek, 1758], Zeznanie mieszczan brzosteckich $w$ sprawie krzywd uczynionych przez opata tynieckiego Stanisława Bartoszewskiego, adresowane do prymasa Polski Adama Ignacego Komorowskiego, ed. B. Stanaszek, [w:] Z dziejów Brzostku. Studia i materiały, t. 2, red. B. Stanaszek, Brzostek 20o9, s. 275-276.

Brzostek, 2 września 1546 r., Jordan Spytek Wawrzyniec z Zakliczyna i Melsztyna oraz Jan Trzecieski z Ratoszyna i Dębicy poświadczaja, przedłożony przez opata tynieckiego, przywilej uposażenia wójtostwa w Brzostku, ed. P. Stanko, tłum. M. Kozera, [w:] Z dziejów Brzostku. Studia i materiały, t. 3, red. B. Stanaszek, Brzostek 2012, s. 54-76. Kozera M., Stan kościoła w mieście Brzostku i Kleciach w świetle wizytacji z 1618 r., „Studia Sandomierskie" 17 (2010) nr 4, s. 109-119.

Parafia Brzostek w świetle wizytacji Radziwiłłowskiej, ed. i tłum. M. Kozera, [w:] Z dziejów

Brzostku. Studia i materiały, t. 2, red. B. Stanaszek, Brzostek 2009, s. 211-228.

Wizytacja kościołów w Brzostku i Kleciach z 1610 roku, ed. i tłum. M. Kozera, [w:] Z dziejów Brzostku. Studia i materiały, t. 2, red. B. Stanaszek, Brzostek 2009, s. 229-244.

Wojnarowska M., Tyburowski K., Parafia Brzostek i Przeczyca w „Liber beneficiorum” Jana Długosza, „Rocznik Brzostecki” 5 (1999-2001), s. 41-67.

Źródła, [w:] Z dziejów Brzostku. Studia i materiały, t. 2, red. B. Stanaszek, Brzostek 2009, s. 185-306 [20 dokumentów dotyczących różnych aspektów funkcjonowania miasta z okresu staropolskiego].

Źródła, [w:] Z dziejów Brzostku. Studia i materiały, t. 3, red. B. Stanaszek, Brzostek 2012, s. 54-161 [16 dokumentów z okresu staropolskiego].

\section{Opracowania}

Cynarski S., Ślawski T., Pisarze sowizdrzalscy z Podgórza, „Pamiętnik Literacki” 55 (1964) z. 1-2, s. 439-449.

Hirschberg A., Stosunki osadnicze $w$ dobrach klasztoru tynieckiego w początkach jego istnienia, Lwów 1925.

Książek M., Układy urbanistyczne niektórych zabytkowych miasteczek $w$ województwie rzeszowskim, „Materiały Muzeum Budownictwa Ludowego w Sanoku” (1973) nr 17-18, s. 7-26. 
Malczewski J., Miasta między Wisłoką a Sanem do początków XVI w. Powstanie - zagospodarowanie - układy przestrzenne, Rzeszów 2006.

Sczaniecki P., Miejska lokacja Brzostku, „Rocznik Brzostecki” 2 (1994), s. 7-11.

Sczaniecki P., Między Brzostkiem a Kleciami (wiadomości o życiu religijnym na schyłku średniowiecza), „Rocznik Brzostecki” 3 (1997), s. 7-11.

Stanaszek B., Brzostek - tradycje historyczne, Brzostek 2014.

Stanaszek B., Jan z Kijan, Januarius Sovizralius, Jan Dzwonowski - dwa pseudonimy, jedno nazwisko? Rzecz o tożsamości plebejskiego poety, „Pamiętnik Literacki” (2013) nr 3, s. 207-216.

Stanaszek B., Ludność i zabudowa Brzostku w świetle inwentarzy z przełomu XVII i XVIII w., [w:] Z dziejów Brzostku. Studia i materiały, t. 2, red. B. Stanaszek, Brzostek 2009, S. 59-112.

Stanaszek B., Stary cmentarz w Brzostku, Brzostek 2013.

Stanaszek B., Terytorium, zabudowa i ludność Brzostku w pierwszym półwieczu rządów austriackich w Galicji, [w:] Z dziejów Brzostku. Studia i materiały, t. 2, red. B. Stanaszek, Brzostek 2009, s. 133-167.

Stanaszek B., Z dziejów Brzostku. Wydarzenia i ludzie, Brzostek 2007. 